\title{
Soil Water Uptake by Amazonian Trees and Simulation of Impacts on Energy Fluxes and Soil Moisture Dynamics at the LBA Flux Towers
}

\author{
Paulo Rodrigo Zanin ${ }^{1}$ \\ ${ }^{1}$ Programa de Pós-Graduação em Clima e Ambiente, Instituto Nacional de Pesquisas da \\ Amazônia, Manaus, AM, Brazil.
}

Received: 26 March 2021 - Accepted: 28 June 2021

\begin{abstract}
Observational and modeling studies show that a deeper soil water uptake by tree roots is required for evapotranspiration in the Amazon Basin. Therefore, this study performed three numerical modeling experiments with different depths of soil water uptake by Amazonian tree roots using the Eta/CPTEC regional climate model. In the "Control" and "Deep Soil Shallow Root" experiments the depth of soil water uptake by tree roots is set up with $2 \mathrm{~m}$, while in the "Deep Soil Deep Root" experiment this depth is set up with $7.2 \mathrm{~m}$, according to the observational studies. The energy balance at the LBA flux towers is better simulated in the "Deep Soil Deep Root" experiment than in other experiments. Moreover, with the "Deep Soil Deep Root" experiment the seasonality of evapotranspiration is reduced in the regions where there is strong seasonality of precipitation, while the seasonality of moisture is reduced in shallow soil layers and increases in the deeper soil layers. In addition, in the regions with strong seasonality of precipitation the deeper soil layers have an inter-annual hydrological memory, and in all regions the soil moisture memory is inversely related to the amount of precipitation, with different behaviors in each soil layer. In conclusion, the deeper soil water uptake by the Amazonian trees is important for the energy balance and soil moisture dynamics in the Amazon Basin.
\end{abstract}

Keywords: Eta/CPTEC regional climate model, Amazon forest, energy and water balance.

\section{Captação de Água do Solo pelas Árvores Amazônicas e Simulação dos Impactos nos Fluxos de Energia e na Dinâmica da Umidade do Solo nas Torres de Fluxo do LBA}

\begin{abstract}
Resumo
Estudos observacionais e de modelagem mostram que uma captação mais profunda de água do solo pelas raízes das árvores é necessária para a evapotranspiração na Bacia Amazônica. Portanto, este estudo realizou três experimentos de modelagem com diferentes profundidades de captação de água do solo pelas raízes das árvores da Amazônia usando o modelo Eta/CPTEC. Nos experimentos "Controle" e "Solo Profundo Raiz Rasa" a profundidade de captação de água no solo pelas raízes das árvores é estabelecida em 2 m, enquanto que no experimento "Solo Profundo Raiz Profunda" essa profundidade é estabelecida em 7,2 m, de acordo com estudos observacionais. O balanço de energia nas torres de fluxo do LBA é melhor simulado no experimento "Solo Profundo Raiz Profunda" do que nos outros experimentos. Além disso, com o experimento "Solo Profundo Raiz Profunda" a sazonalidade da evapotranspiração é reduzida nas regiões com forte sazonalidade da precipitação, enquanto que a sazonalidade da umidade do solo é reduzida nas camadas rasas e aumentada nas camadas mais profundas do solo. Também foi verificado que nas regiões com forte sazonalidade da precipitação as camadas mais profundas do solo têm uma memória hidrológica interanual, e que a memória da umidade do solo em todas as regiões analisadas tem uma relação inversa com a quantidade de precipitação, com diferentes comportamentos em cada camada do solo. Em conclusão, a captação mais profunda de água no solo pelas árvores Amazônicas é importante para o balanço de energia e dinâmica da umidade do solo na Bacia Amazônica.
\end{abstract}

Palavras-chave: modelo climático regional Eta/CPTEC, floresta Amazônica, balanço de água e energia. 


\section{Introduction}

Soil moisture significantly influences the estimation of the water balance in climate models. This is mainly due to its capacity to maintain the hydroclimatic characteristics of past events, to influence evapotranspiration, runoff and recycling of precipitation (Koster and Suarez, 2001). However, the representation of the feedback mechanisms between soil moisture and precipitation still has limitations in simulations of climate models (Moon et al., 2019).

Dirmeyer et al. (2009) found that in the regions under the influence of monsoon rains, a feedback mechanism occurs between soil moisture and precipitation recycling in the post-monsoon phase. Figure 6 of these authors, that shows the soil moisture memory in overlap areas with positive and significant correlations between soil moisture and evapotranspiration, and between soil moisture and precipitation recycling, exhibits the regions where the following processes occur: 1) precipitation determines soil moisture, 2) soil moisture determines evapotranspiration due to the hydrological memory of past events, and 3) evapotranspiration reinforces hydrological anomalies by precipitation recycling. During the austral winter season, the process described above is widespread in the Amazon Basin south of the Equator. In this region, Dirmeyer et al. (2009) found that the memory of water in the soil lasts approximately 40 days. However, this study used gridded moisture products which take into account only the first meters of soil depth.

Tomasella et al. (2008), in turn, found that water storage in the soil of the central Amazon presents different temporal behaviors as a function of depth. The layers closest to the surface respond rapidly to the precipitation events at the same time as they lose water rapidly by vertical drainage. However, the contrary occurs in the deep layers. For the soil profile at a depth of $8 \mathrm{~m}$, Jipp et al. (1998) found, at a site in the southeast Amazon, that water recharge between $1 \mathrm{~m}$ and $8 \mathrm{~m}$ depth has an autocorrelation of 0.80 with 98 days of delay. It is important to mention that Nepstad et al. (1994) found that deep rooting is homogeneous in the Brazilian Amazon forest, and although they concentrated their hydrological analysis in up to $8 \mathrm{~m}$ of soil depth, they found roots with a maximum depth of approximately $18 \mathrm{~m}$.

According to Hodnett et al. (1996), most of the Amazon evapotranspiration is supplied by the water stored in the $0 \mathrm{~m}$ to $3.6 \mathrm{~m}$ layer. Analyzing the layer mentioned at sites in the center, southwest and southeast of the Amazon Basin, these authors found a maximum seasonal variation of water storage of $200 \mathrm{~mm}, 701 \mathrm{~mm}$ and $724 \mathrm{~mm}$, respectively. Also, according to these authors the water demand for evapotranspiration is also supplied by storage in the soil below $3.6 \mathrm{~m}$ during the dry season, reaching
$51 \%$ at the site to southwest and $38 \%$ at the site to southeast of the basin. Bruno et al. (2006), in their turn, found at a site located in the eastern Amazon Basin, that in the wet season approximately $56 \%$ of the water used in evapotranspiration comes from the soil layer up to $2 \mathrm{~m}$ deep, gradually diminishing until the depth of $7 \mathrm{~m}$. On the other hand, in the dry season $\sim 28 \%$ is supplied by the layer of up to $2 \mathrm{~m}$, with a practically uniform contribution of layers up to $7 \mathrm{~m}(10 \%$ to $15 \%)$. As to the deepest soil layers analyzed, from $8 \mathrm{~m}$ to $10 \mathrm{~m}$, their contribution to evapotranspiration is $6 \%(8 \%)$ in the wet (dry) season. At a site in the central Amazon, Broedel et al. (2017) found that approximately $80 \%(100 \%)$ of the water uptake by the tree roots for evapotranspiration occurs in the soil layer up to $3 \mathrm{~m}(4.8 \mathrm{~m})$ deep, and water uptake may occur below these layers during extreme droughts. According to these authors there is no evidence of water uptake by the tree roots below $6.4 \mathrm{~m}$. However, this varies from region to region in the Amazon according to seasonality of precipitation.

Although most of the evapotranspiration is supplied by the first few meters of the soil profile, it is important to consider the occurrence of a hydraulic redistribution in Amazon soils with low hydraulic conductivity through the tree roots (Oliveira et al., 2005; Bruno et al., 2006). According to Oliveira et al. (2005), during the dry season in the daytime the major (vertical) root and lateral (horizontal) roots extract water from soil, while during the nighttime only the major root extracts water from soil, and the lateral roots release water. However, during the wet season, especially at night, only the lateral roots uptake water from the soil, while the major root releases water. According to these authors, the ascending flow is important for evapotranspiration in the dry season, while the descending flow only occurs after precipitations under conditions where the deep soil is drier than the surface soil, which is a common condition in the transition from the dry season to the wet season.

On the other hand, climate models exhibit significant uncertainties about precipitation over the Amazon Basin (Solman et al., 2013), and numerical modeling studies of land surface-atmosphere interactions in the Amazon Forest with the increased soil depth and soil root zone improved the results (Harper et al., 2010; Rocha et al., 2012). Using the Simple Biosphere (SiB) model coupled to a single atmospheric column model, Harper et al. (2010) compared simulations with water stress, in which soil moisture uptake by tree roots reached the depth of $3.5 \mathrm{~m}$, and without water stress, in which soil moisture uptake by tree roots reached the depth of $10 \mathrm{~m}$. These authors found that simulation without water stress reproduced the sensible and latent heat fluxes and the intensity of precipitation in the dry season better than the simulation with water stress. These authors also found that, in simulations without water stress there is more moisture at 
lower levels of the atmosphere. On the other hand, using the RegCM3 regional climate model coupled with BATS land-surface scheme, Rocha et al. (2012) verified that an increase in the soil depth and soil root zone has the same effect on the evapotranspiration as the reduction of water loss in the bottom soil layer by free drainage. These authors compared simulations with a soil depth at $4.5 \mathrm{~m}$ and soil root zone at $3.0 \mathrm{~m}$, namely the RegZhang experiment, with soil depth at $8.0 \mathrm{~m}$ and soil root zone at $4.0 \mathrm{~m}$, namely the RegArain experiment, and with a reduction of $40 \%$ in saturated hydraulic conductivity in the bottom soil layer of the RegZhang experiment, namely the RegClaris experiment. According to these authors, the evapotranspiration is larger in the RegClaris and RegArain than in the RegZhang experiment. Thus, the Bowen ratio and precipitation is better simulated in the Amazon region by the RegClaris and RegArain than in the RegZhang experiment. Moreover, it should be emphasized that modeling experiments incorporating a scheme of dynamic distribution of roots also provided a better simulation of the latent heat fluxes in the Amazon (Wang et al., 2016).

However, the modeling studies presented above focus only on the effect of the soil moisture uptake by the Amazonian trees over the energy fluxes and atmospheric dynamics. Therefore, the objective of this study is to analyze the behavior of moisture in each soil layer in three different regions of the Amazon Forest. The amount, seasonality and hydrological memory of soil moisture in each layer of soil column are analyzed with help of the Eta/ CPTEC regional climate model. However, before this analysis the validation of modeling experiments is made with energy fluxes observed at some LBA flux towers.

\section{Material and Methods}

\subsection{Eta/CPTEC regional climate model}

For the modeling experiments, the Eta/CPTEC regional climate model (Mesinger et al., 2012) is used. This model discretizes the equations with grid $\mathrm{E}$ of Arakawa (Arakawa and Lamb, 1977). In the vertical this model has the $\eta$ coordinate (Mesinger, 1984). The Janjic method (1979) is used to calculate the finite differences in space, and the temporal integration is performed with split-explicit technique (Gadd, 1978). The Eta/CPTEC regional climate model is being widely used in South America in weather (Chou, 1996; Bustamante et al., 2005; Moura et al., 2010; Seluchi et al., 2011), seasonal (Chou et al., 2005; Chou et al., 2012a), and multi-decadal (Pesquero et al., 2010; Chou et al., 2012b; Chou et al., 2014a) simulations. It is also used in the evaluation of impacts of land cover change (Rodriguez et al., 2014) and climate change by increasing greenhouse gases scenarios (Chou et al., 2014b; Lyra et al., 2018).
It should be mentioned that the version of Eta/ CPTEC regional climate model used in this study is validated for long term simulations over South America (Pesquero et al., 2010; Chou et al., 2012b). The main parametrizations utilized are Betts-Miller-Janjic for convection (Betts and Miller, 1986; Janjic, 1994), MellorYamada 2.5 level for turbulence (Mellor and Yamada, 1982), Geophysical Fluid Dynamics Laboratory for longwave and short-wave radiation (Fels and Schwarzkopf, 1975; Lacis and Hansen, 1974) and Zhao for cloud microphysics (Zhao et al., 1997). For simulation of land surface processes the Noah LSM scheme (Chen et al., 1997; Ek et al., 2003) with prescribed annual cycle of vegetation greenness is used. The moisture and temperature in the soil column are parametrized considering 4 layers with root layers varying according to vegetation type (maximum of 4 root layers). The bottom soil layer is $2 \mathrm{~m}$ deep, and below this layer the water is lost by free drainage. The canopy conductance is calculated as a function of leaf area index, air temperature, solar radiation, vapor pressure deficit and soil moisture availability (Jarvis type). Regarding the soil moisture factor controlling stomatal resistance, this is a linear function of soil moisture between wilting point and field capacity. More details about this land surface scheme coupled with the Eta model are shown in Ek et al. (2003 and references therein).

In this work, the Eta/CPTEC regional climate model is operated in hydrostatic version mode, with a horizontal resolution of $40 \mathrm{~km}$ and vertical resolution of 38 levels with model top at $50 \mathrm{hPa}$. The post processed domain is between the latitudes $8^{\circ} \mathrm{N}$ and $39^{\circ} \mathrm{S}$ and between the longitudes $42^{\circ} \mathrm{W}$ and $81^{\circ} \mathrm{W}$. The model is integrated from 1998 to 2009, in which 1 year of spin-up is discarded. This spin-up time for atmospheric conditions has already been used by Pesquero et al. (2010) in their decadal simulation over South America. The initial and boundary conditions are obtained from Era-Interim reanalyses (Dee et al., 2011), with a spatial resolution of $0.75^{\circ}(\sim 80 \mathrm{~km})$ and temporal resolution of $6 \mathrm{~h}$. The topography dataset is obtained from Global 30 Arc-Second Elevation GTOPO30 (USGS/EROS). The soil data (Zobler, 1986) distinguish 9 types of soils at a spatial resolution of $1^{\circ}$ $(\sim 110 \mathrm{~km})$. The vegetation map is prepared by a merger between the global map of the University of Maryland (Defries et al., 1998; Hansen et al., 2000) and the map made by Project to Update the Representation of Vegetation in CPTEC's Numerical Models - PROVEG (Sestini et al., 2002) for the Brazilian territory, with a spatial resolution of $1 \mathrm{~km}$. This vegetation map used the $\mathrm{SSiB}$ vegetation cover types (Dorman and Sellers, 1989).

\subsection{Modeling experiments}

The soil layers of the three experiments and root layers for the Evergreen Broadleaf Trees in the Amazon region are shown in Fig. 1. The Control (CTL) experiment 


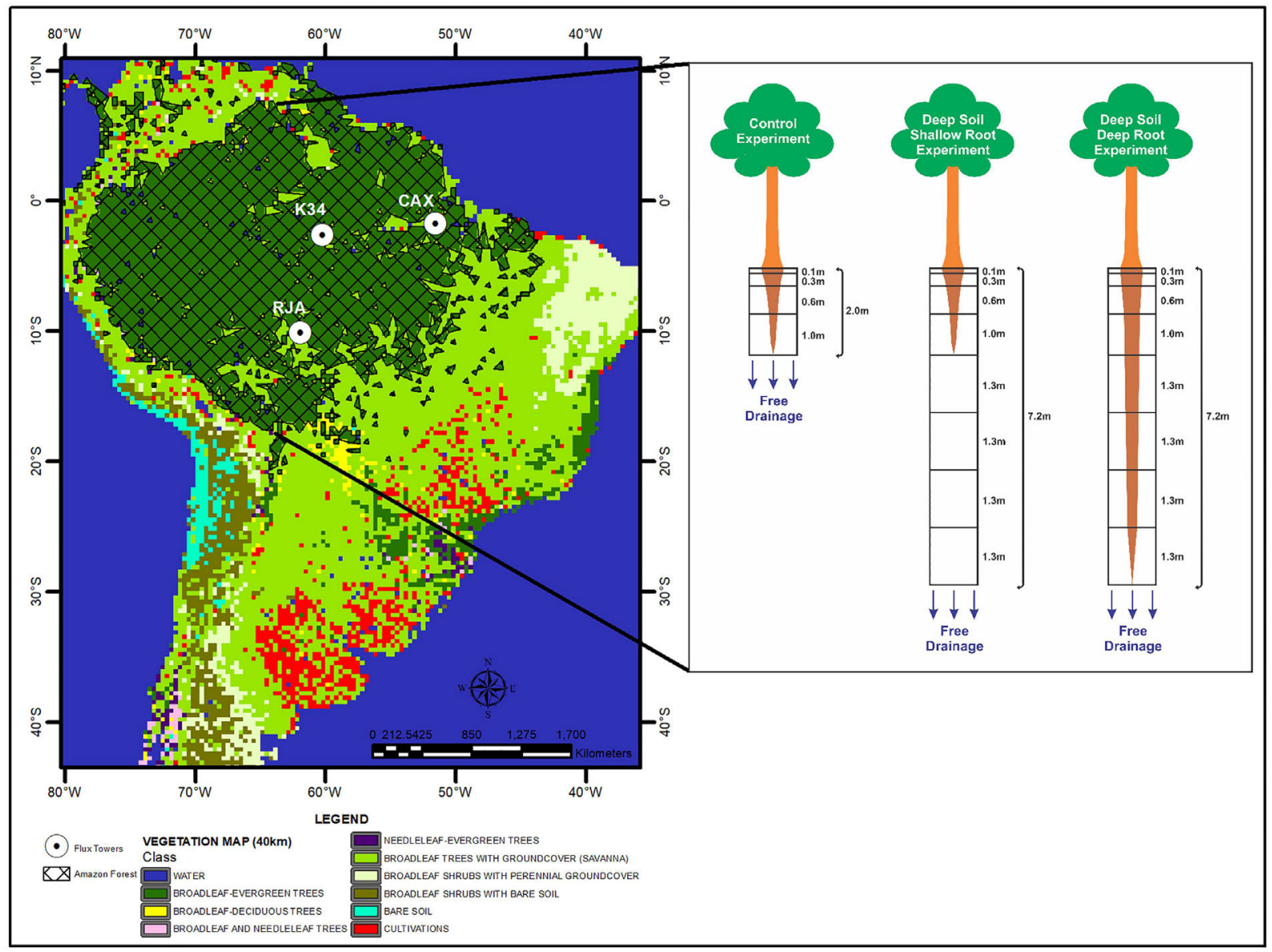

Figure 1 - Vegetation map (interpolated to $40 \mathrm{~km}$ ) and location of the flux towers. The Amazon Forest where the tree roots are increased in Deep Soil Deep Root experiment is shown in this figure. The soil layers and the tree roots zone in soil by Control, Deep Soil Shallow Root and Deep Soil Deep Root experiments are also shown.

is set up with 4 soil layers and a total soil depth of $2 \mathrm{~m}$. These values of soil layers and depth and root layers are the default of the Eta/CPTEC regional climate model, used in long term simulations validated over South America (Pesquero et al., 2010; Chou et al., 2012b). The Deep Soil and Shallow Root (DSSR) experiment is set up with 8 soil layers and the total soil depth of $7.2 \mathrm{~m}$. This soil depth value is defined according to the required depth of the water uptake by tree roots for evapotranspiration in the Amazon Forest, verified by previous observational studies (Jipp et al., 1998; Bruno et al., 2006; Broedel et al., 2017). However, the root layers in this experiment are the same as in the Control experiment. The Deep Soil and Deep Root (DSDR) experiment is set up with 8 soil layers and the total soil depth of $7.2 \mathrm{~m}$. On the other hand, in this experiment the roots of the Amazon Forest (Evergreen Broadleaf Trees in the Amazon region) can uptake water from the 8 layers of soil depth.

The initial soil moisture and temperature for each of the shallower four soil layers are obtained from a monthly climatology, calculated based on each of the four soil layers of the Era-Interim reanalysis. In the deeper four soil layers, the monthly climatological values for soil moisture and temperature are calculated from the deeper soil layer (fourth layer) of the Era-Interim reanalysis.

\subsection{Simulation evaluation}

These three experiments are evaluated on a monthly time scale at flux towers points. Precipitation, near surface temperature, net radiation, ground heat flux, sensible heat flux and latent heat flux from 3 flux towers (Saleska et al., 2013) are used to evaluate the simulated energy and water balances. A short description of these flux towers is shown in Table 1 and its locations are shown in Fig. 1. A summary of measurement techniques of some variables of these flux towers can be obtained from von Randow et al. (2004).

At the location of the towers, the performance of simulation of the annual cycle of latent heat flux (LE), sensible heat flux $(\mathrm{H})$ and ground heat flux $(\mathrm{G})$ are evaluated. As a complement, the annual cycle of near surface temperature $(\mathrm{T})$, net radiation $(\mathrm{RN})$, precipitation $(\mathrm{P})$, soil moisture (SM) and Bowen ratio (B) are also discussed. To verify the agreement in seasonal variability of $G, H$ and 
Table 1 - Flux towers site description.

\begin{tabular}{|c|c|c|c|c|c|c|c|}
\hline $\mathrm{N}^{\mathrm{o}}$ & Code & Location & Measurement period & Basin & Vegetation & Soil depth* & WTD* \\
\hline 1 & CAX & $\begin{array}{c}1.719797^{\circ} \mathrm{S} \\
51.458181^{\circ} \mathrm{W}\end{array}$ & $\begin{array}{c}01 / 1999 \text { to } \\
07 / 2003\end{array}$ & Amazon & $\begin{array}{c}\text { Evergreen } \\
\text { Broadleaf } \\
\text { Forest }\end{array}$ & 3 to $4 \mathrm{~m}$ & $\begin{array}{c}\sim 10 \mathrm{~m} \\
\text { (wet season) }\end{array}$ \\
\hline 2 & K34 & $\begin{array}{c}2.609097^{\circ} \mathrm{S} \\
60.209297^{\circ} \mathrm{W}\end{array}$ & $\begin{array}{c}06 / 1999 \text { to } \\
09 / 2006\end{array}$ & Amazon & $\begin{array}{c}\text { Evergreen } \\
\text { Broadleaf } \\
\text { Forest }\end{array}$ & $>15 \mathrm{~m}$ & $35 \mathrm{~m}$ \\
\hline 3 & RJA & $\begin{array}{l}10.083194^{\circ} \mathrm{S} \\
61.930903^{\circ} \mathrm{W}\end{array}$ & $\begin{array}{c}03 / 1999 \text { to } \\
11 / 2002\end{array}$ & Amazon & $\begin{array}{c}\text { Evergreen } \\
\text { Broadleaf } \\
\text { Forest }\end{array}$ & 1.2 to $4 \mathrm{~m}$ & NA \\
\hline
\end{tabular}

*: According to Restrepo-Coupe et al. (2013, and references therein); NA: Not available; WTD: Water Table Depth.

LE between the simulated and observed data, the coefficient of correlation (r) according to Montgomery and Runger (2003) is used. To calculate the coefficient of correlation, the logarithm with base 10 of the data is used. To verify the overestimates or underestimates in mean monthly values of the annual cycle of $\mathrm{G}, \mathrm{H}$ and $\mathrm{LE}$, the mean bias is used. It is important to mention that to calculate the annual cycle of the different variables as a monthly mean, only the months with no gap data in either sensible or latent heat flux are considered.

Next, the water balance components and soil moisture memory during period of simulation in both experiments are analyzed at the locations of the flux towers. To verify the amount and seasonal variability of the precipitation, evapotranspiration and soil moisture in all soil layers, the mean and standard deviation of time series are used, respectively. The spin-up time for the soil moisture equilibrium is evaluated using the criterion of de Goncalves et al. (2006), in which the percent value of difference between the monthly average soil moisture for the previous year and the monthly average soil moisture in the current year must be equal to or less than $1 \%$. The average value of soil moisture in each month is calculated using soil moisture integrated from all soil layers.
The soil moisture memory in each soil layer is obtained according to Dirmeyer et al. (2009). According to these authors the soil moisture memory is measured as the average time required for the confidence level of the soil moisture autocorrelation function to fall to less than $99 \%$. The autocorrelation function is obtained according to Wey (2006), and the statistical significance at 0.01 is obtained by two-tailed Student-t test.

\section{Results and Discussion}

\subsection{Evaluation of energy fluxes}

Figure 2 and Table 2 show the simulated and observed annual cycle of sensible, latent and ground heat fluxes at the CAX, K34 and RJA flux towers, situated in the Amazon Forest within the Amazon Basin. As a complement, the annual cycles of near surface temperature, net radiation, precipitation, volumetric soil moisture in the whole soil profile and Bowen ratio are also shown in Fig. 2. The metrics used to evaluate the performance of experiments are described in sub-section 2.3. However, before discussing the results of this study, it is important to mention that Chou et al. (2007), when evaluating short-

Table 2 - CAX, K34 and RJA flux towers. Correlation coefficient (r) and mean Bias (Simulated minus Observed).

\begin{tabular}{|c|c|c|c|c|c|c|c|c|c|c|c|}
\hline \multirow[t]{2}{*}{ EXP. } & \multirow[t]{2}{*}{ PAR. } & \multicolumn{3}{|c|}{ CAX } & \multicolumn{4}{|c|}{ K34 } & \multicolumn{3}{|c|}{ RJA } \\
\hline & & $\mathrm{H}$ & LE & B & $\mathrm{H}$ & LE & $\mathrm{G}$ & B & $\mathrm{H}$ & LE & B \\
\hline \multirow[t]{2}{*}{ CTL } & $\mathrm{r}$ & -0.06 & 0.62 & 0.50 & 0.89 & -0.19 & 0.26 & 0.52 & 0.81 & 0.24 & 0.74 \\
\hline & Bias & 50.75 & 13.83 & 1.18 & 7.47 & 42.73 & 0.51 & -0.05 & 20.68 & 47.28 & 0.07 \\
\hline \multirow[t]{2}{*}{ DSSR } & $\mathrm{r}$ & -0.10 & 0.70 & 0.54 & 0.91 & -0.08 & 0.17 & 0.59 & 0.86 & 0.28 & 0.77 \\
\hline & Bias & 46.29 & 18.31 & 0.75 & 6.70 & 43.97 & 0.46 & -0.06 & 19.69 & 47.71 & 0.06 \\
\hline \multirow[t]{2}{*}{ DSDR } & $\mathrm{r}$ & 0.26 & 0.36 & 0.22 & 0.88 & 0.58 & 0.28 & 0.61 & 0.85 & 0.25 & 0.76 \\
\hline & Bias & 20.86 & 43.86 & 0.01 & 0.93 & 47.69 & 0.39 & -0.11 & 16.91 & 51.51 & 0.03 \\
\hline
\end{tabular}

It is important to mention that the correlation coefficient is used to evaluate the seasonal variability. EXP.: Experiment; PAR.: Parameter; CTL: Control experiment; DSSR: Deep Soil Shallow Root experiment; DSDR: Deep Soil Deep Root experiment; LE: Latent heat flux (W $\mathrm{m}^{-2}$ ); H: Sensible heat flux $\left(\mathrm{W} \mathrm{m}^{-2}\right)$; G: Ground heat flux $\left(\mathrm{W} \mathrm{m}^{-2}\right)$; B: Bowen ratio. 
term simulations from the Eta/CPTEC regional climate model using observations from the RJA flux tower, found that sensible and latent heat fluxes are overestimated by the model, and recommended the correction of the exces-

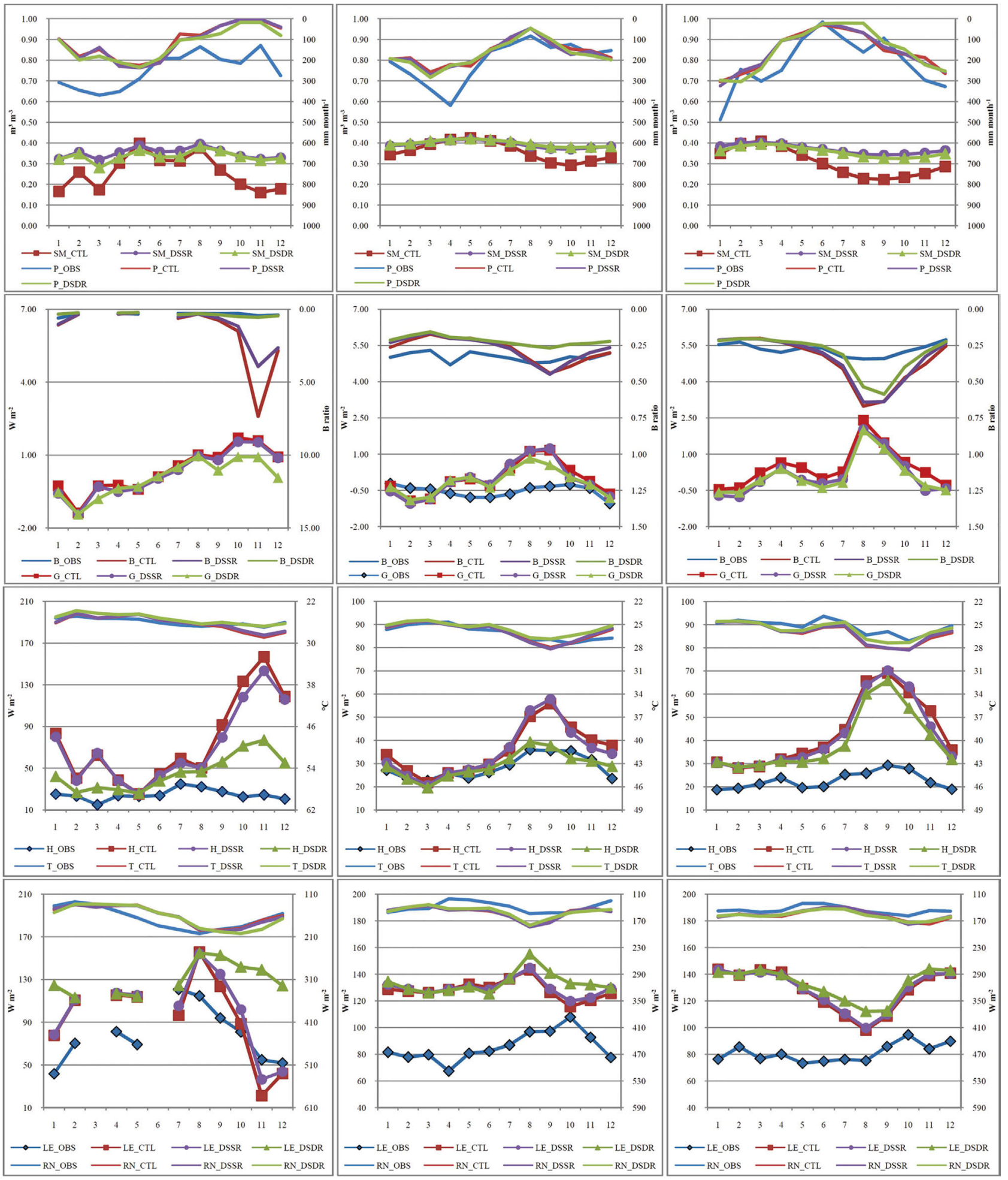

Figure 2 - Left column: CAX flux tower. Center column: K34 flux tower. Right column: RJA flux tower. Top row: Precipitation (P) in mm month ${ }^{-1}$ and volumetric soil moisture (SM) in $\mathrm{m}^{3} \mathrm{~m}^{-3}$. Second top row: Ground heat flux $(\mathrm{G})$ in $\mathrm{W} \mathrm{m}^{-2}$ and Bowen $(\mathrm{B})$ ratio. Third top row: Sensible heat flux (H) in $\mathrm{W}$ $\mathrm{m}^{-2}$ and near surface temperature (T) in ${ }^{\circ} \mathrm{C}$. Bottom row: Latent heat flux (LE) in $\mathrm{W} \mathrm{m}^{-2}$ and net radiation (RN) in $\mathrm{W} \mathrm{m}{ }^{-2}$. OBS: Data from flux tower; CTL: Control experiment; DSSR: Deep Soil Shallow Root experiment; DSDR: Deep Soil Deep Root experiment. 
sive incoming shortwave radiation simulated by the model.

Figure 2 shows that despite the small changes in the simulated precipitation between the three experiments, the changes in simulated volumetric soil moisture in the whole soil profile are large between the CTL and the others experiments. The differences in simulated volumetric soil moisture in the whole soil profile between the DSSR and DSDR experiments are small, and the seasonality is smaller in these experiments than in the CTL experiment. However, the ground heat flux reduces in the DSDR experiment in relation to the DSSR and CTL experiments, and according to Table 2 is better simulated in the DSDR experiment at the K34 flux tower, than the others experiments.

Consequently, the seasonal variability of the Bowen ratio is better simulated in the DSDR experiment than in the CTL and DSSR experiments in the K34 flux tower, while the mean bias is better simulated in the DSDR experiment than in the CTL and DSSR experiments in the CAX and RJA flux towers, as shown in Table 2. It is important to mention that the seasonal variability of the Bowen ratio is better simulated in the DSDR experiment than in the CTL experiment in the RJA tower flux.

The predominantly better performance of the simulated Bowen ratio in the DSDR experiment than in the CTL and DSSR experiments is mainly due to improved simulation of the mean bias of sensible heat flux in all flux towers with increased soil depth of water uptake by the tree roots in the DSDR experiment, as shown in Fig. 2 and Table 2. Regarding the seasonal variability of sensible heat flux, the DSDR experiment is better than CTL and DSSR only in the CAX flux tower. In the RJA flux tower the seasonal variability of sensible heat flux is better simulated in the DSDR than in the CTL experiment. On the other hand, Fig. 2 and Table 2 show that only the seasonal variability of the latent heat flux in the K34 flux tower and mean bias in the RJA flux tower are better simulated in the DSDR experiment than in the CTL and DSSR experiments.

It should be noted in Fig. 2 that the seasonality of observed and simulated energy fluxes is dominated by the seasonality of the net radiation, as found by other authors at these sites (Juarez et al., 2007; Rocha et al., 2009), and the differences between the experiments are dominated by the volumetric soil moisture. When the volumetric soil moisture in the whole soil profile is similar in all experiments, the sensible and latent heat fluxes are also very similar in all experiments. However, when the volumetric soil moisture is reduced in all experiments the sensible and ground heat fluxes, the Bowen ratio and the near surface temperature increase, while the latent heat flux decreases.

With the increase in depth of soil column in the DSSR experiment in relation to the CTL experiment, the sensible and ground heat fluxes are reduced while the latent heat flux increases (see mean bias in Table 2). However, these differences are small and mainly occur during the relatively dry season (Fig. 2). This is due to more water in the surface soil layer available for direct soil evaporation in the DSSR experiment than in the CTL experiment during this season (not shown). On the other hand, as the DSDR experiment has greater availability and smaller seasonality of soil moisture associated with deeper soil water uptake by the tree roots, the sensible and ground heat fluxes significantly reduces while the latent heat flux significantly increases in relation to the CTL and DSSR experiments during the relatively dry season in these three flux towers (Fig. 2).

Juarez et al. (2007) found in the southern Amazon that the water recharge of deep soils during the wet season maintains evapotranspiration during the subsequent relatively dry season. Thus, the increase of the latent heat flux in the DSDR experiment is due to the greater soil water reservoir for precipitation during the rainy season compared to the CTL experiment, and due to deeper soil water uptake by the Amazonian tree roots compared with the DSSR experiment.

On the other hand, it is important to observe that with the increases in the depth of the soil water uptake by the Amazonian tree roots, the latent heat flux is largely overestimated in the Amazon Forest. This overestimate in the DSDR experiment is due to the association of the greater soil water availability to trees throughout the year in this experiment, with the parametrization of the "Soil Moisture Factor Controlling Stomatal Resistance", also named " $\beta$ Factor". According to Fig. 3 of Niu et al. (2011), that shows the relation between different $\beta$ factors and soil moisture for sand, loam and clay soils, the $\beta$ Factor by Noah type, used in this version of the Eta/CPTEC regional climate model, has a linear relation with the soil moisture because it is a direct function of the soil moisture. Thus the evapotranspiration has linear increases with the increases in the soil moisture. On the other hand, the $\beta$ Factor by SSiB type and by CLM type is a function of the matric potential of soil, and thus has a non-linear relation with the soil moisture. The two latter $\beta$ factors are available in the new land surface scheme recently coupled in the Eta/CPTEC model (Pilotto et al., 2017) and can improve the simulation of latent heat flux in the Amazon Forest.

\subsection{Simulated hydrological variables}

Figure 3 shows the simulated soil moisture in all soil layers (1998-2009) associated with simulated precipitation and evapotranspiration (1999-2009). Table 3 shows the time required for the soil moisture integrated from all layers to stabilize in each experiment. Table 4 shows the standard deviation and mean values of time series (1999-2009) of the simulated precipitation, evapo- 

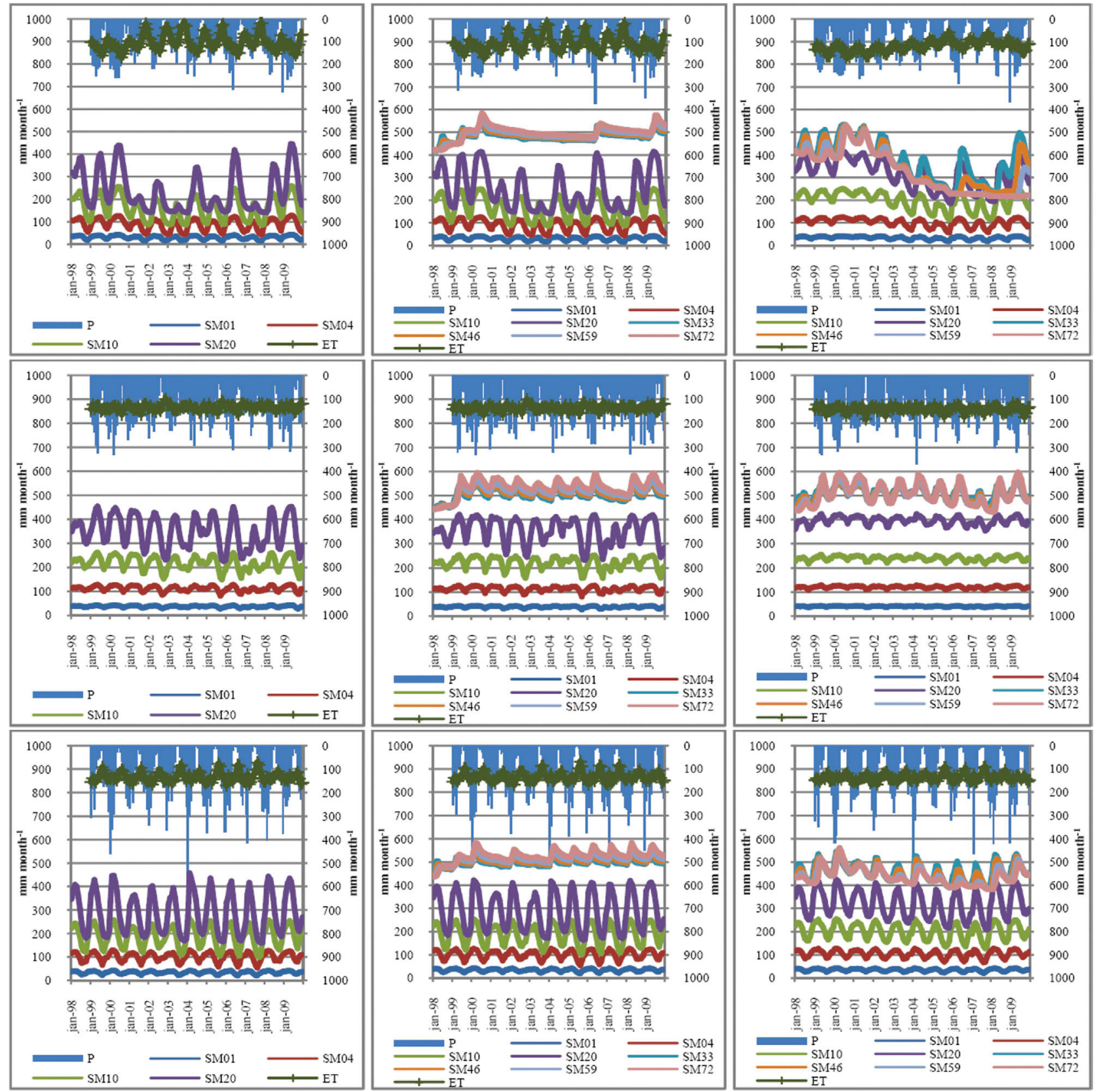

Figure 3 - Top row: Simulations at the CAX flux tower. Center row: Simulations at the K34 flux tower. Bottom row: Simulations at the RJA flux tower. In left column the Control experiment. In center column the Deep Soil Shallow Root experiment. In right column the Deep Soil Deep Root experiment. SM01: Soil moisture in first layer; SM04: Soil moisture in second layer; SM10: Soil moisture in third layer; SM20: Soil moisture in fourth layer; SM33: Soil moisture in fifth layer; SM46: Soil moisture in sixth layer; SM59: Soil moisture in seventh layer; SM72: Soil moisture in eighth layer; P: Precipitation; ET: Evapotranspiration. All variables in $\mathrm{mm} \mathrm{month}^{-1}$.

Table 3 - Number of months required for the average monthly soil moisture integrated from all layers to reach a $1 \%$ difference between the same months from two consecutive years.

\begin{tabular}{lccc}
\hline FT & CTL & DSSR & DSDR \\
\hline CAX & 6 & 3 & 3 \\
K34 & 8 & 18 & 17 \\
RJA & 2 & 12 & 12 \\
\hline
\end{tabular}

FT: Flux Tower; CTL: Control experiment; DSSR: Deep Soil Shallow Root experiment; DSDR: Deep Soil Deep Root experiment. transpiration and soil moisture in all soil layers for the CTL experiment, while Table 5 shows them for the DSSR experiment, and Table 6 shows them for the DSDR experiment. The use of mean and standard deviation to evaluate the experiments is explained in sub-section 2.3.

According to Table 3, the soil moisture becomes stabilized in up to one year in all experiments in the RJA and 
CAX flux towers. However, in the K34 flux tower, it only becomes stabilized before one year in the CTL experiment. The DSSR and DSDR experiments in this flux tower need around 1.5 year to stabilize. K34 is the flux tower with the smallest seasonality and the largest amount of precipitation, according to Tables 4, 5 and 6 . On the other hand, it is curious to observe that while the time soil moisture takes to stabilize in K34 and RJA flux towers increases from the CTL experiment to the DSSR and DSDR experiments, an inverse pattern occurs in the CAX flux tower. This flux tower receives the smallest amount of precipitation, according to Tables 4, 5 and 6 . Therefore, Table 3 shows that the soil moisture in shallow soil (CTL experiment) stabilizes faster in the Amazon regions with a larger seasonality of precipitation than in the regions with smaller seasonality, while the soil moisture in shallow and deep soil together (DSSR and DSDR experiments) is stabilized faster in the Amazon regions with smaller amounts of precipitation than in the regions with a larger volume of rain.

It is possible to observe in Fig. 3 that one year of spin-up is sufficient to define the pattern (although the amplitude varies according to precipitation) of the annual cycle of soil moisture in all soil layers, despite the behavior after 2001 in deeper soil layers at the CAX flux tower, that is associated with the change in length of the dry season and the amount of water precipitated during the wet season, which will be explained next. Therefore, and not-

Table 4 - Control experiment. Mean (u) and standard deviation (sd) of the time series of precipitation (P), evapotranspiration (ET) and soil moisture (SM) in all soil layers.

\begin{tabular}{|c|c|c|c|c|c|c|c|c|c|c|c|c|}
\hline \multirow[t]{2}{*}{ FT } & \multicolumn{2}{|c|}{ SM01 } & \multicolumn{2}{|c|}{ SM04 } & \multicolumn{2}{|c|}{ SM10 } & \multicolumn{2}{|c|}{ SM20 } & \multicolumn{2}{|c|}{ ET } & \multicolumn{2}{|c|}{$\mathrm{P}$} \\
\hline & $\mathrm{sd}$ & $\mathrm{u}$ & $\mathrm{sd}$ & $\mathrm{u}$ & $\mathrm{sd}$ & $\mathrm{u}$ & $\mathrm{sd}$ & $\mathrm{u}$ & $\mathrm{sd}$ & $\mathrm{u}$ & $\mathrm{sd}$ & $\mathrm{u}$ \\
\hline CAX & 7.58 & 30.72 & 24.40 & 88.87 & 51.46 & 161.94 & 88.91 & 229.87 & 34.90 & 103.80 & 86.32 & 116.35 \\
\hline K34 & 3.46 & 37.58 & 10.85 & 112.44 & 28.24 & 219.36 & 67.12 & 349.85 & 11.45 & 133.73 & 71.99 & 169.18 \\
\hline RJA & 5.66 & 34.38 & 18.41 & 101.35 & 45.30 & 189.21 & 88.78 & 287.51 & 20.12 & 132.78 & 117.81 & 160.31 \\
\hline
\end{tabular}

It is important to mention that the standard deviation is used to evaluate the seasonal variability. FT: Flux Tower. All variables in mm month ${ }^{-1}$.

Table 5 - Same as in Table 4, but for the Deep Soil Shallow Root experiment.

\begin{tabular}{|c|c|c|c|c|c|c|c|c|c|c|}
\hline \multirow[t]{2}{*}{ FT } & \multicolumn{2}{|c|}{ SM01 } & \multicolumn{2}{|c|}{ SM04 } & \multicolumn{2}{|c|}{ SM10 } & \multicolumn{2}{|c|}{ SM20 } & \multicolumn{2}{|c|}{ SM33 } \\
\hline & $\mathrm{sd}$ & $\mathrm{u}$ & $\mathrm{sd}$ & $\mathrm{u}$ & $\mathrm{sd}$ & $\mathrm{u}$ & $\mathrm{sd}$ & $\mathrm{u}$ & $\mathrm{sd}$ & $\mathrm{u}$ \\
\hline CAX & 7.59 & 31.27 & 24.43 & 90.83 & 51.18 & 167.34 & 88.03 & 242.17 & 18.06 & 482.83 \\
\hline K34 & 3.35 & 37.80 & 10.06 & 113.23 & 24.79 & 221.41 & 53.08 & 355.18 & 19.57 & 506.37 \\
\hline RJA & 5.62 & 34.40 & 18.08 & 101.55 & 43.90 & 189.88 & 83.05 & 289.63 & 15.58 & 498.64 \\
\hline \multirow[t]{2}{*}{ FT } & \multicolumn{2}{|c|}{ SM46 } & \multicolumn{2}{|c|}{ SM59 } & \multicolumn{2}{|c|}{ SM72 } & \multicolumn{2}{|c|}{ ET } & \multicolumn{2}{|c|}{$\mathrm{P}$} \\
\hline & sd & $\mathrm{u}$ & sd & $\mathrm{u}$ & sd & $\mathrm{u}$ & sd & $\mathrm{u}$ & $\mathrm{sd}$ & $\mathrm{u}$ \\
\hline CAX & 18.07 & 489.03 & 20.20 & 496.20 & 25.58 & 506.05 & 33.55 & 108.12 & 90.94 & 120.05 \\
\hline K34 & 17.83 & 514.13 & 19.29 & 524.72 & 25.72 & 542.67 & 11.02 & 135.30 & 75.19 & 171.48 \\
\hline RJA & 13.93 & 506.90 & 14.58 & 517.20 & 19.07 & 532.82 & 19.44 & 133.14 & 115.09 & 157.98 \\
\hline
\end{tabular}

Table 6 - Same as in Table 4, but for the Deep Soil Deep Root experiment.

\begin{tabular}{|c|c|c|c|c|c|c|c|c|c|c|}
\hline \multirow[t]{2}{*}{ FT } & \multicolumn{2}{|c|}{ SM01 } & \multicolumn{2}{|c|}{ SM04 } & \multicolumn{2}{|c|}{ SM10 } & \multicolumn{2}{|c|}{ SM20 } & \multicolumn{2}{|c|}{ SM33 } \\
\hline & $\mathrm{sd}$ & $\mathrm{u}$ & sd & $\mathrm{u}$ & sd & $\mathrm{u}$ & $\mathrm{sd}$ & $\mathrm{u}$ & $\mathrm{sd}$ & $\mathrm{u}$ \\
\hline CAX & 6.21 & 33.91 & 17.89 & 101.84 & 38.41 & 197.56 & 66.86 & 312.61 & 90.46 & 376.89 \\
\hline K34 & 1.51 & 39.83 & 4.31 & 119.85 & 8.72 & 239.55 & 16.04 & 396.97 & 24.05 & 511.33 \\
\hline RJA & 5.12 & 35.10 & 15.39 & 104.83 & 34.30 & 201.98 & 60.85 & 319.46 & 39.46 & 460.12 \\
\hline \multirow[t]{2}{*}{ FT } & \multicolumn{2}{|c|}{ SM46 } & \multicolumn{2}{|c|}{ SM59 } & \multicolumn{2}{|c|}{ SM72 } & \multicolumn{2}{|c|}{ ET } & \multicolumn{2}{|c|}{$\mathrm{P}$} \\
\hline & $\mathrm{sd}$ & $\mathrm{u}$ & $\mathrm{sd}$ & $\mathrm{u}$ & $\mathrm{sd}$ & $\mathrm{u}$ & $\mathrm{sd}$ & $\mathrm{u}$ & $\mathrm{sd}$ & $\mathrm{u}$ \\
\hline CAX & 94.95 & 344.64 & 96.52 & 323.63 & 95.35 & 314.37 & 22.22 & 120.44 & 83.27 & 120.96 \\
\hline K34 & 27.98 & 507.44 & 33.82 & 507.23 & 44.65 & 515.32 & 12.19 & 140.49 & 74.01 & 172.71 \\
\hline RJA & 37.59 & 451.44 & 36.69 & 442.89 & 37.71 & 438.24 & 14.71 & 136.36 & 117.13 & 149.09 \\
\hline
\end{tabular}


withstanding the time of 1.5 year required to stabilize the soil moisture in the DSSR and DSDR experiments at the K34 flux tower, one year of spin-up of soil moisture is considered adequate in this study.

According to Tables 4, 5 and 6 in all flux towers the soil moisture in the first four soil layers of the DSDR experiment has a smaller amplitude between the wet and dry seasons than in the four soil layers in the CTL and DSSR experiments. With exception of the first two soil layers, the DSSR experiment also has a smaller seasonality than the CTL experiment. In the mean of the time series, the DSDR experiment retains more water in its first four soil layers than in the CTL and DSSR experiments. The DSSR experiment also retains more water in its first four soil layers than the CTL experiment.

It is also possible to observe in Tables 4, 5 and 6, as well as in Fig. 3, that as a consequence of the changes in the soil moisture, the evapotranspiration in the DSDR experiment increases in all flux towers and has a smaller seasonality at the CAX and RJA flux towers than in the CTL and DSSR experiments. The evapotranspiration in the DSSR experiment increases and has a smaller seasonality in all flux towers than the evapotranspiration in the CTL experiment. According to Tables 4, 5 and 6, the K34 flux tower has the smaller seasonality in precipitation and evapotranspiration than the other flux towers, thus the greater soil water availability to the tree roots in the DSDR experiment increases the seasonality of evapotranspiration in relation to the CTL and DSSR experiment.

The depth of the water uptake by the tree roots was not increased in the DSSR experiment. However, the greater amount of water stored in the soil in this experiment, including in the root soil layers, slightly increases the evapotranspiration due to more water available to the tree roots and also to direct evaporation from the soil surface.

Regarding the last four soil layers in the DSSR and DSDR experiments, it is possible to observe in Fig. 3 and Tables 4, 5 and 6 that the DSSR experiment has a smaller seasonality than in the DSDR experiment, and with exception of the fifth layer at the K34 flux tower, the DSSR has a greater amount of water than the DSDR experiment. The differences between these two experiments are mainly due to the fact that in the DSSR experiment the last four soil layers only lost water by free drainage at the bottom soil column, while in the DSDR experiment the water is also lost by water uptake by tree roots. In the last four soil layers in the DSDR experiment, it is possible to observe in Fig. 3 that the recharge of these layers is sensible to the length of the dry season and the amount of water precipitated during the wet season. This pattern increases from the fifth to the eighth layers, where the fifth and sixth layers are more sensible to the amount of water precipitated during the wet season, while the seventh and eighth layers are more sensible to the length of the dry season.

These patterns of soil moisture in different layers, and at different locations of the flux towers analyzed, are also perceptible in the soil moisture memory (Table 7). In the Table 7 it is possible to observe that the soil moisture memory increases with increases of soil depth in the CTL and DSDR experiments, while in the DSSR experiment memory is practically static along the soil profile (K34 and JAR), or that there is no well defined pattern (CAX). In the CTL experiment the memory ranges from 2 to 4 months, in the DSSR it ranges from 2 to 14 months, while in the DSDR experiment it ranges from 2 to 54 months. Associating the results shown in Table 7 with a previous analysis, it is possible to observe that the soil moisture memory is inversely related to the amount of precipitation. $\mathrm{K} 34$ and the RJA are the flux towers with the largest amount of precipitation, and in consequence are the towers with the smallest soil moisture memory. On the other hand, CAX is the flux tower with the smallest amount of precipitation, resulting in the largest soil moisture memory in its deeper soil layers.

With exception of the K34 flux tower, all the other towers show inter-annual soil moisture memory in their deeper soil layers in the DSDR experiment. The interannual effect of the hydrological memory in the Amazon Basin has also been found in previous studies (Tomasella et al., 2008; Guedes et al., 2013). At the location of the

Table 7 - Simulated soil moisture memory in all soil layers from the both experiments (Monthly time scale).

\begin{tabular}{|c|c|c|c|c|c|c|c|c|c|}
\hline \multirow[t]{2}{*}{ Bottom soil layer (m) } & \multicolumn{3}{|c|}{ CAX } & \multicolumn{3}{|c|}{ K34 } & \multicolumn{3}{|c|}{ RJA } \\
\hline & CTL & DSSR & DSDR & CTL & DSSR & DSDR & CTL & DSSR & DSDR \\
\hline 0.1 & 3 & 3 & 4 & 2 & 2 & 2 & 2 & 2 & 2 \\
\hline 0.4 & 3 & 3 & 4 & 3 & 2 & 2 & 2 & 2 & 2 \\
\hline 1.0 & 3 & 3 & 5 & 3 & 3 & 3 & 2 & 2 & 3 \\
\hline 2.0 & 4 & 4 & 28 & 3 & 3 & 3 & 2 & 2 & 3 \\
\hline 3.3 & & 14 & 38 & & 3 & 3 & & 2 & 3 \\
\hline 4.6 & & 13 & 40 & & 3 & 3 & & 3 & 4 \\
\hline 5.9 & & 12 & 48 & & 3 & 3 & & 3 & 17 \\
\hline 7.2 & & 12 & 54 & & 3 & 3 & & 3 & 28 \\
\hline
\end{tabular}

CTL: Control experiment; DSSR: Deep Soil Shallow Root experiment; DSDR: Deep Soil Deep Root experiment. 
K34 flux tower, that has the maximum simulated soil moisture memory of 3 months, Tomasella et al. (2008) found an inter-annual hydrological memory due to water stored in the soil. However, this effect found by these authors is due to the saturated soil zone, dominated by the water table (around $35 \mathrm{~m}$ deep; see Table 1), and this version of the Eta/CPTEC model only considers the water in the non-saturated soil zone.

As the water table in the Amazon Basin is predominantly shallow (modeling data average for the entire watershed is from $7.5 \mathrm{~m}$ to $9.5 \mathrm{~m}$ [Fan and MiguezMacho, 2010]), the groundwater influences surface water, soil moisture and evapotranspiration in the Amazon Basin (Miguez-Macho and Fan, 2012a, 2012b). Therefore, the modeling results of this study have a limitation due to the fact that it does not consider the influence of aquifer dynamics below the soil column and water table oscillation between aquifer and soil layers on the surface processes. Thus, the soil moisture memory in the deepest soil layers can be larger than the values shown in Table 7. On the other hand, the parametrization of groundwater (aquifer and water table) is available in the new land surface scheme recently coupled in the Eta/CPTEC regional climate model (Pilotto et al., 2017).

\section{Conclusions}

With the increases in the depth of the soil water uptake by the Amazonian tree roots, the Eta/CPTEC regional climate model improved the simulation of the amount and seasonal variability of the sensible heat flux, such as the seasonal variability of the latent heat flux. However, the latent heat flux is largely overestimated in the Amazon Forest. This overestimate in the "Deep Soil Deep Root" experiment is due to the association of the greater soil water availability to trees throughout the year in this experiment, with the parametrization of the "Soil Moisture Factor Controlling Stomatal Resistance". As this parametrization in this version of the Eta/CPTEC regional climate model has a linear relation to the soil moisture, the evapotranspiration has linear increases with the increases in the soil moisture.

The time for soil water to become stabilized varies from 2 months in $2 \mathrm{~m}$ of soil depth at the RJA flux tower to around 18 months in $7.2 \mathrm{~m}$ of soil depth at the K34 flux tower. Moreover, it is found that the moisture in shallow soil becomes stabilized faster in the Amazon regions with a larger seasonality of precipitation, while the moisture in shallow and deep soil together becomes stabilized faster in Amazon regions with a smaller amount of precipitation.

The deepest soil water uptake by the Amazonian tree roots in the "Deep Soil Deep Root" experiment reduces the seasonality of evapotranspiration in the regions with strong seasonality of precipitation (northeast and south of the Amazon Basin), while it increases in the region with weak seasonality of precipitation (center part of the Amazon Basin). In all regions, the presence of tree roots in deeper soil layers reduces the seasonality of moisture in shallow soil layers (between the surface and $2 \mathrm{~m}$ ), while increasing it in the deeper soil layers (between 2 and $7.2 \mathrm{~m}$ ). This is due to the reduction of the amount of soil water uptake by tree roots from shallow soil layers while this uptake increases from the deeper soil layers, mainly during the relatively dry season.

The soil moisture memory is inversely related to the amount of precipitation in each region, where the intermediate soil layers (between 2 and $4.6 \mathrm{~m}$ ) are influenced by the amount of water precipitated during the wet season, while the deeper soil layers (between 4.6 and $7.2 \mathrm{~m}$ ) are influenced by the length of the relatively dry season. In the regions with strong seasonality of precipitation the deeper soil layers have an inter-annual soil moisture memory, reaching $\sim 2$ years in the southern and 4.5 years in the northeastern parts of the Amazon Basin. On the other hand, in the region with weak seasonality of precipitation all the soil layers have an inter-monthly soil moisture memory, of up to 3 months in deeper layers. It is important to mention that the presence of tree roots in deeper soil layers increases the soil moisture memory in most soil column in regions with strong seasonality of precipitation. Moreover, these results have a limitation due to the fact that the model does not parametrize the aquifer dynamics below the soil column and water table oscillation between aquifer and soil layers. Therefore, the soil moisture memory in the deepest soil layers can be larger than the values found in this study.

Finally, it is concluded that the deeper soil water uptake by the Amazonian trees is important for energy balance and soil moisture dynamics in the Amazon Basin. Moreover, this process also improves the simulation of energy fluxes in the Amazon Forest by the Eta/CPTEC regional climate model. Therefore, it is recommended that in future studies the influence of deeper soil water uptake by the Amazonian trees on the atmospheric dynamics on a regional scale be evaluated. Moreover, it is important to mention that the limitations in the modeling results of this study, due to the parametrization of the "Soil Moisture Factor Controlling Stomatal Resistance" and the lack of parametrization of groundwater dynamics, can be solved with the new land surface scheme recently coupled in the Eta/CPTEC regional climate model (Pilotto et al., 2017).

\section{Acknowledgments}

The author acknowledges support from the CAPES of Brazil. Also he is grateful to ProjEta team (CPTEC/INPE), especially Chou Sin Chan, André de Arruda Lyra, Gustavo Sueiro Medeiros, Gracielle Chagas and Isabel Lopes Pilotto Domingues by their orientations and support with the Eta/CPTEC regional climate model. This study was 
financed in part by the Coordenação de Aperfeiçoamento de Pessoal de Nível Superior - Brasil (CAPES) - Finance Code 001 .

\section{References}

ARAKAWA, A.; LAMB, V.R.; Computational design of the basic dynamical process of the UCLA general model. Methods of Computational Physics, v. 17, p. 173-265, 1977.

BETTS, A.K.; MILLER, M.J. A new convective adjustment scheme. Part II: Single column tests using Gate Wave, Bomex, Atex and Arctic air-mass data sets. Quarterly Journal of the Royal Meteorological Society, v. 112, p. 693-709, 1986.

BROEDEL, E.; TOMASELLA, J.; CÂNDIDO, L.A.; VON RANDOW, C. Deep soil water dynamics in an undisturbed primary forest in central Amazonia: Differences between normal years and the 2005 drought. Hydrological Processes, v. 31, n. 9, p. 1749-1759, 2017.

BRUNO, R.D.; ROCHA, H.R.; FREITAS, H.C.; GOULDEN, M.L.; MILLER, S.D. Soil moisture dynamics in an eastern Amazonian tropical forest. Hydrological Processes, v. 20, n. 12, p. 2477-2489, 2006.

BUSTAMANTE, J.F.; CHOU, S.C.; ROZANTE, J.R.; GOMES, J.L. Uma avaliação da previsibilidade de tempo do modelo Eta para a América do Sul. Revista Brasileira de Meteorologia, v. 20, n. 1, p. 59-70, 2005.

CHEN, F.; JANJIC, Z.; MITCHELL, K. Impact of atmospheric surface-layer parameterizations in the new land-surface scheme of the NCEP mesoscale Eta model. BoundaryLayer Meteorology, v. 85, p. 391-421, 1997.

CHOU, S.C. Modelo regional Eta. Climanálise, v. 1, n. Ed. Especial, 1996.

CHOU, S.C.; BUSTAMANTE, J.F.; GOMES, J.L. Evaluation of Eta Model seasonal precipitation forecasts over South America. Nonlinear Processes in Geophysics, v. 12, n. 4, p. 537-555, 2005.

CHOU, S.C.; MARENGO, J.A.; DERECZYNSKI, P.V.W.; MANZI, A.O. Comparison of CPTEC GCM and Eta Model results with observational data from the Rondonia LBA reference site, Brazil. Journal of the Meteorological Society of Japan, v. 85A, p. 25-42, 2007.

CHOU, S.C.; PILOTTO, I.L.; NOBRE, P. Seasonal climate hindcasts with Eta model nested in CPTEC coupled ocean atmosphere general circulation model. Theoretical and Applied Climatology, v. 110, p. 437-456, 2012a.

CHOU, S.C.; KAY, G.; BUSTAMANTE, J.F.; ALVES, L.M.; LYRA, A.A.; SUEIRO, G.; et al. Downscaling of South America present climate driven by 4-member HadCM3 runs. Climate Dynamics, v. 38, p. 635-653, 2012b.

CHOU, S.C.; LYRA, A.; MOURÃO, C.; DERECZYNSKI, C.; PILOTTO, I.; GOMES, J. et al. Evaluation of the Eta simulations nested in three global climate models. American Journal of Climate Change, v. 3, n. 5, p. 438-454, 2014a.

CHOU, S.C.; LYRA, A.; MOURÃO, C.; DERECZYNSKI, C.; PILOTTO, I.; GOMES, J. et al. Assessment of climate change over South America under RCP 4.5 and 8.5 down- scaling scenarios. American Journal of Climate Change, v. 3, n. 5, p. 512-527, 2014b.

DEE, D.P.; UPPALA, S.M.; SIMMONS, A.J.; BERRISFORD, P.; POLI, P.; KOBAYASHI, S. et al. The ERA-Interim reanalysis: configuration and performance of the data assimilation system. Quarterly Journal of the Royal Meteorological Society, v. 137, n. 656, p. 553-597, 2011.

DEFRIES, R.; TOWNSHEND, J.R.G.; HANSEN, M. Continuos fields of vegetation characteristics at the global scale at $1 \mathrm{~km}$ resolution. Journal of Geophysical Research, v. 104, n. D14, p. 16911-16925, 1998.

DE GONCALVES, L.G.G.; SHUTTLEWORTH, W.J.; BURKE, E.J.; HOUSER, P.; TOLL, D.L.; RODELL, M.; ARSENAULT, K. Toward a South America land data assimilation system: Aspects of land surface model spin-up using the simplified simple biosphere. Journal of Geophysical Research, v. 111, D17110, 2006.

DIRMEYER, P.A.; SCHLOSSER, C.A.; BRUBAKER, K.L. Precipitation, recycling, and land memory: An integrated analysis. Journal of Hydrometeorology, v. 10, n. 1, p. $278-288,2009$.

DORMAN, J.L.; SELLERS, P.J. A global climatology of Albedo, roughness length and stomatal resistance for atmospheric general circulation models as represented by the simple biosphere model ( $\mathrm{SiB}$ ). Journal of Applied Meteorology, v. 28, n. 9, p. 833-855, 1989.

EK, M.B.; MITCHELL, K.E.; LIN, Y.; ROGERS, E.; GRUMMEN, P.; KOREN, V.; GAYNO, G.; TARPLEY, J.D. Implementation of NOAH land surface advances in the National Centers for Environmental Prediction operational mesoscale Eta model. Journal of Geophysical Research, v. 108, n. D22, p. 8851, 2003.

FAN, Y.; MIGUEZ-MACHO, G. Potential groundwater contribution to Amazon dry-season evapotranspiration. Hydrology and Earth System Sciences, v. 14, n. 10, p. 2039-2056, 2010.

FELLS, S.B.; SCHWARZKOPF, M.D. The simplified exchange approximation. A new method for radiative transfer calculations. Journal of the Atmospheric Sciences, v. 32, n. 7, p. 1475-1488, 1975.

GADD, A.J. A split-explicit integration scheme for numerical weather prediction. Quarterly Journal of the Royal Meteorological Society, v. 104, n. 441, p. 569-582, 1978.

GUEDES, A.E.D.S.; CANDIDO, L.A.; ESPIRITO SANTO, A.R.S. Variabilidade do estoque de água continental e sua relação com as cheias e vazantes extremas na Amazônia. Revista Ambiente e Água, v. 8, n. 2, p. 88-99, 2013.

HANSEN, M.C.; DEFRIES, R.S.; TOWNSHEND, J.R.G.; SOHLBERG, R. Global land cover classification at $1 \mathrm{~km}$ spatial resolution using a classification tree approach. International Journal of Remote Sensing, v. 21, n. 6-7, p. 1331-1364, 2000.

HARPER, A.B.; DENNING, A.S.; BAKER, I.T.; BRANSON, M.D.; PRIHODKO, L.; RANDALL, D.A. Role of deep soil moisture in modulating climate in the Amazon rainforest. Geophysical Research Letters, v. 37, L05802, 2010.

HODNETT, M.G.; OYAMA, M.D.; TOMASELLA, J.; MARQUES FILHO, A.O. Comparisons of long-term soil water storage behaviour under pasture and forest in three areas of 
Amazonia. In: Amazonian Deforestation and Climate. GASH, J.H.C.; NOBRE, C.A. ROBERTS, J.M.; VICTORIA, R.L. (eds). West Sussex: John Wiley and Sons, p. $57-77,1996$.

JANJIC, Z.I. Forward-backward scheme modified to prevent two-grid-internal noise and its application in sigma coordinate models. Contributions to Atmospheric Physics, v. 52, n. 1, p. $69-84,1979$.

JANJIC, Z.I. The step montain coordinate model: further developments of the convection, viscous sublayer, and turbulence closure schemes. Monthly Weather Review, v. 122, n. 5, p. 927-945, 1994

JIPP, P.H.; NEPSTAD, D.C.; CASSEL, D.K.; REIS DE CARVALHO, C. Deep soil moisture storage and transpiration in forests and pastures of seasonally dry Amazonia. Climate Change, v. 39, p. 395-412, 1998.

JUAREZ, R.I.N.; HODNETT, M.G.; FU, R.; GOULDEN, M.L.; VON RANDOW, C. Control of dry season evapotranspiration over the Amazonian forest as inferred from observations at a Southern Amazon forest site. Journal of Climate, v. 20, n. 12, p. 2827-2839, 2007.

KOSTER, R.D.; SUAREZ, M.J. Soil moisture memory in climate models. Journal of Hydrometeorology, v. 2, n. 6, p. 558-570, 2001.

LACIS, A.A.; HANSEN, J.E. A parameterization of the absorption of solar radiation in earth's atmosphere. Journal of the Atmospheric Sciences, v. 31, n. 1, p. 118-133, 1974.

LYRA, A.; TAVARES, P.; CHOU, S.C.; SUEIRO, G.; DEREEZYNSKI, C.; SONDERMANN, M. et al. Climate change projections over three metropolitan regions in Southeast Brazil using the non-hydrostatic Eta regional climate model at 5-km resolution. Theoretical and Applied Climatology, v. 132, p. 663-682, 2018.

MELLOR, G.L.; YAMADA, T. Development of a turbulence closure models for geophysical fluid problems. Reviews of Geophysics and Space Physics, v. 20, n. 4, p. 851-875, 1982.

MESINGER, F. A blocking for representation of mountains in atmospheric models. Rivista Di Meteorologia Aeronautica, v. 44, n. 1-4, p. 195-202, 1984.

MESINGER, F.; CHOU, S.C.; GOMES, J.L.; JOVIC, D.; BASTOS, P.; BUSTAMANTE, J.F. et al. An upgraded version of the Eta model. Meteorology and Atmospheric Physics, v. 116, v. 3-4, p. 63-79, 2012.

MIGUEZ-MACHO, G.; FAN, Y. The role of groundwater in the Amazon water cycle: 1. Influence on seasonal streamflow, flooding and wetlands. Journal of Geophysical Research, v. 117, D15113, 2012a.

MIGUEZ-MACHO, G.; FAN, Y. The role of groundwater in the Amazon water cycle: 2 . Influence on seasonal soil moisture and evapotranspiration. Journal of Geophysical Research, v. 117, D15114, 2012b.

MOON, H.; GUILLOD, B.P.; GUDMUNDSSON, L.; SENEVIRATNE, S.I. Soil moisture effects on afternoon precipitation occurrence in current climate models. Geophysical Research Letters, v. 46, n. 3, p. 1861-1869, 2019.

MONTGOMERY, D.C.; RUNGER, G.C. Applied Statistics and Probability for Engineers. Rosewood Drive: John Wiley $\&$ Sons, $3^{\circ}$ ed., 822 p., 2003.
MOURA, R.G.; HERDIES, D.L.; MENDES, D.; MENDES, M.C.D. Avaliação do modelo regional Eta utilizando as análises do CPTEC e NCEP. Revista Brasileira de Meteorologia, v. 25, n. 1, p. 46-53, 2010.

NEPSTAD, D.C.; CARVALHO, C.R.; DAVIDSON, E.A.; JIPP, P.H.; LEFEBVRE, P.A.; NEGREIROS, G.H.; et al. The role of deep roots in the hydrological and carbon cycles of Amazonian forests and pastures. Nature, v. 372, p. 666669, 1994.

NIU, G.Y.; YANG, Z.L.; MITCHELL, K.E.; CHEN, F.; EK, M.B.; BARLAGE, M. et al. The community Noah land surface model with multiparameterization options (NoahMP): 1. Model description and evaluation with local-scale measurements. Journal of Geophysical Research, v. 116, D12109, 2011.

OLIVEIRA, R.S.; DAWSON, T.E.; BURGESS, S.S.; NEPSTAD, D.C. Hydraulic redistribution in three Amazonian trees. Oecologia, v. 145, n. 3, p. 354-363, 2005.

PESQUERO, J.F.; CHOU, S.C.; NOBRE, C.A.; MARENGO, J.A. Climate downscaling over South America for 19611970 using the Eta Model. Theoretical and Applied Climatology, v. 99, n. 1, p. 75-93, 2010.

PILOTTO, I.L.; RODRÍGUEZ, D.A.; CHOU, S.C.; TOMASELLA, J.; SAMPAIO, G.; GOMES, J.L. Effects of the surface heterogeneities on the local climate of a fragmented landscape in Amazonia using a tile approach in the Eta/NoahMP model. Quarterly Journal of the Royal Meteorological Society, v. 143, n. 704, p. 1565-1580, 2017.

RESTREPO-COUPE, N.; ROCHA, H.R.; HUTYRA, L.R.; ARAUJO, A.C.; BORMA, L.S.; CHRISTOFFERSEN, B.; et al. What drives the seasonality of photosynthesis across the Amazon basin? A cross-site analysis of eddy flux tower measurements from the Brasil flux network. Agricultural and Forest Meteorology, v. 182-183, p. 128-144, 2013.

RODRIGUEZ, D.A.; CHOU, S.C.; TOMASELLA, J.; DEMARIA, E.M.C. Impacts of landscape fragmentation on simulated precipitation fields in the Amazonian sub-basin of JiParaná using the Eta model. Theoretical and Applied Climatology, v. 115, n. 1-2, p. 121-114, 2014.

ROCHA, H.R.; MANZI, A.O.; SHUTTLEWORTH, J. Evapotranspiration. In: Amazon and Global Change. KELLER, M., BUSTAMANTE, M., GASH, J., SILVA DIAS, P. (eds). Washington, D.C.,: American Geophysical Union, 2009.

ROCHA, R.P.; CUADRA, S.V.; REBOITA, M.S.; KRUGER, L.F.; AMBRIZZI, T.; KRUSCHE, N. Effects of RegCM3 parametrizations on simulated rainy season over South America. Climate Research, v. 52, p. 253-265, 2012.

SALESKA, S.R.; ROCHA, H.R.; HUETE, A.R.; NOBRE, A.D.; ARTAXO, P.E.; SHIMABUKURO, Y.E. LBA-ECO CD-32 Flux Tower Network Data Compilation, Brazilian Amazon: 1999-2006. Oak Ridge: ORNL DAAC, 2013.

SELUCHI, M.E.; CHOU, S.C.; GRAMANI, M. A case study of winter heavy rainfall event over the Serra do Mar in Brazil. Geofísica Internacional, v. 50, n. 1, p. 41-56, 2011.

SESTINI, M.F.; ALVALÁ, R.C.S.; MELLO, E.M.K.; VALERIANO, D.M.; CHOU, S.C.; NOBRE, C.A. et al. Elaboração de Mapas de Vegetação para Utilização em Modelos Meteorológicos e Hidrológicos. São José dos Campos: Instituto Nacional de Pesquisas Espaciais, 2002. 
SOLMAN, S.A.; SANCHEZ, E.; SAMUELSSON, P.; ROCHA, R.P.; LI, L.; MARENGO, J. et al. Evaluation of an ensemble of regional climate model simulations over South America driven by the ERA-Interim reanalysis: model performance and uncertainties. Climate Dynamics, v. 41, p. 1139-1156, 2013.

TOMASELLA, J.; HODNETT, M.G.; CUARTAS, L.A.; NOBRE, A.D.; WATERLOO, J.; OLIVEIRA, S.M. The water balance of an Amazonia micro-catchment: the effect of interannual variability of rainfall on hydrological behavior. Hydrological Processes, v. 22, n. 13, p. 2133-2147, 2008.

von RANDOW, C.; MANZI, A.O.; KRUIJT, B.; OLIVEIRA, P.J.; ZANCHI, F.B.; SILVA, R.L. et al. Comparative measurements and seasonal variations in energy and carbon exchange over forest and pasture in South West Amazonia. Theoretical and Applied Climatology, v. 78, p. 5-26, 2004.
WANG, Y.; XIE, Z.; JIA, B. Incorporation of a Dynamic Root Distribution into CLM4.5: Evaluation of Carbon and Water Fluxes over the Amazon. Advances in Atmospheric Sciences, v. 33, n. 9, p. 1047-1060, 2016.

WEY, W.S. Time Series Analysis: Univariate and Multivariate Methods. Hoboken: Addison Wesley, 2nd ed., 2006.

ZHAO, Q.; BLACK, T.L.; BALDWIN, M.E. Implementation of the cloud prediction scheme in the Eta model at NCEP. Weather and Forecasting, v. 12, p. 697-712, 1997.

ZOBLER, L. A World Soil File for Global Climate Modeling. New York: NASA Goddard Institute for Space Studies, 1986.

License information: This is an open-access article distributed under the terms of the Creative Commons Attribution License (type CC-BY), which permits unrestricted use, distribution and reproduction in any medium, provided the original article is properly cited. 